\title{
Methods to ensure the effectiveness of educator historians and the specifics of their applications
}

Armine Eprikyan ${ }^{\mathrm{a}}$ *

Suggested Citation:

New Trends and Issues Proceedings on Humanities and Social Sciences.

Abstract 
Trends and Issues Proceedings on Humanities and Social Sciences.

1. Article

PVR 
Trends and Issues Proceedings on Humanities and Social Sciences.

$\bullet$

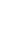

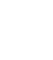

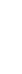

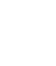

$\bullet$

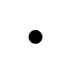

:

$\bullet$ 
Trends and Issues Proceedings on Humanities and Social Sciences.

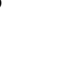

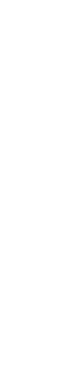

"mosaic,"

Mosaic Method 
Trends and Issues Proceedings on Humanities and Social Sciences.

\section{References}

101 Ideas for Innovative Teachers

Drevnyaya Rus' i velikaya step' [Ancient Russia and the great steppe]

Usutschi ughetsuyts tetr: Orva dasi plan [Guidebook for

Teachers: Daily Lesson Plans]

Nastol'naya kniga prepodavatelya istorii [Desk reference for history teachers] 